\title{
Historical consciousness and traditional Buddhist narratives
}

\author{
Rita M Gross
}

Correspondence: grossrm@uwec.edu Dept. of Philosophy and Religious Studies, University of WisconsinEau Claire, Eau Claire, WI 54701, USA

\begin{abstract}
In this paper, I intend to explore some of the issues that come up when I tried to teach academically grounded, accurate, non-sectarian history of Buddhism at Buddhist dharma centers. First among these issues is that Western Buddhists can be quite fundamentalist in their approach to Buddhism and take many narratives literally. Chief among these, especially for Mahāyāna Buddhists, is the Heart Sütra, which they believe was actually given by the historical Buddha during his lifetime because of the setting in which this narrative is placed. To explain why Mahāyāna teachings did not take hold for about four hundred years, they add the belief that the historical Buddha realized that people were not ready for those teachings, so he had them concealed among the nägas, from where Nāgārjuna retrieved them. Historians obviously do not take this story seriously as history and seek for historical causes and conditions that led to the development of Mahāyāna ideas some four hundred years after the death of the Buddha. I will argue, first, that key Buddhist teachings, especially teachings on all-pervasive impermanence and on interdependent origination, can be used to verify historical accounts of the origins of Mahāyāna Buddhism. In other words, to accept the more sensible and reasonable account given by modern historians is not to abandon traditional Buddhist beliefs and teachings. It is rather to appeal to traditional Buddhist teachings that provide more adequate explanations of the origins of Mahāyāna Buddhism that the traditional mythic narrative. Second, I will discuss how the mythic account can be interpreted symbolically and will argue that symbols should not be considered as less important or real than facts. Only those who buy completely into the model of scientific materialism provided by the European enlightenment would not understand that in religions, symbols are as meaningful as facts.
\end{abstract}

\section{Background}

For many years, I taught Buddhism to non-Buddhists at a regional state university, whether as part of my world religions course, in a semester long course on Buddhism, or in units on Buddhism in courses on Japanese and Chinese religions. In my view, what I could actually communicate about Buddhism in those courses was quite superficial. At the midpoint of my career as a university professor of the comparative study of religion, I also began to function as a Buddhist dharma teacher in the Buddhist organizations to which I belong, as well for other Buddhist groups. Now, since my retirement from the university, I have been teaching very widely as a senior dharma teacher (lopon in Tibetan, àcārya in Sanskrit). This teaching is not a "hang out your shingle" operation. I am authorized to teach according to the protocols of the lineage

(c) 2014 Gross; licensee Springer. This is an Open Access article distributed under the terms of the Creative Commons Attribution License (http://creativecommons.org/licenses/by/2.0), which permits unrestricted use, distribution, and reproduction in any medium, provided the original work is properly cited. 
of my primary affiliation and I have taught somewhat advanced Buddhist materials in that context. I also continue to teach for a wide variety of other Buddhist organizations.

Previously, those of us who have allegiance to both a dharma tradition and the values of academic scholarship have mainly defended our abilities to function in the academy, proving that our participation in a dharma tradition did not wreck our scholarship. Indeed, many such scholars have hidden their dharma affiliations, at least from their academic colleagues. Others of us have argued that the academy needs the perspectives of well-trained scholar-practitioners to represent the dharma traditions accurately and fairly. I have contributed publications in both these areas. However, I think it is now time to reverse the arrow of influence, exploring how the modern academic study of religion is relevant to our dharma traditions and how it changes our views of certain aspects of our dharma traditions. In this paper, I will explore the tensions and promise of the hyphen joining the two words "scholar" and "practitioner", especially as they relate to teaching Buddhist history to Buddhist practitioners. I will explore what happens when an academically trained university professor who is also a Buddhist practitioner becomes a dharma teacher and takes her academic training and perspectives into dharma teaching.

\section{Normative curricula at Western Buddhist centers}

For these tensions to be clearer to readers who are not familiar with how Western Buddhist sanghas teach Buddhism to their own members, it is necessary to report something about the usual curriculum at a Western Buddhist center. At a dharma center, students receive very little, if any, overall instruction about Buddhism as a whole; they only study their own lineage and school, and in some cases are discouraged from receiving teachings from other teachers, whether verbal or written. There is almost no study of Buddhist history and what little there is focuses only on the particular lineage and school of Buddhism with which the center is affiliated. Most of that meager training in Buddhist history is sectarian, justifying whatever school the center belongs to as "what the Buddha really taught". If anything is taught about other forms of Buddhism, what is usually taught is how they either did not receive the Buddha's full teachings or how they erroneously accepted newly minted scriptures as Buddhavacana, the words of the Buddha. The teachers and directors of these centers would justify their choices about what to teach by claiming that they are teaching spirituality and that accurate understandings of Buddhist history or empathetic appreciation for other forms of Buddhism are irrelevant to the primary goal of aiding students aiming for deep spiritual transformation and even enlightenment. They also often claim that students will become confused if they hear different teachings or teachings that contradict what they are being taught at their dharma center. In addition most dharma teachers are completely lacking in any academic training in Buddhist history and comparative studies in religion. In their defense, it must be said that it is very difficult for a non-academic practitioner to study Buddhist history; there are very few accessible sources for such study. That is one reason why I took up the project of teaching accurate and non-sectarian history of Buddhism at Buddhist dharma centers. 


\section{Buddhist history for Buddhist practitioners}

What began as a simple service project has morphed into a major concern as I have discovered that certain questions of great interest to practitioners, such as the origins of Mahāyāna Buddhism, are not well understood by professional scholars of Buddhist history. But I have also discovered, somewhat to my shock, that Western practitioners of Buddhism can be as naively literalist in their readings of traditional Buddhist narratives as any Christian fundamentalist. Thus, my project quickly took on a second agenda, that of trying to reconcile students' unconscious and inevitable immersion in the paradigm engendered by the European enlightenment with their commitments to Buddhism. This reconciliation must involve a way for Buddhists to value traditional narratives without following many adherents of Western religions into fundamentalism and literalism. This second aspect of my project will be the major focus of this essay.

For the past five years (2007-11), I have taught a very serious course on Buddhist history at the shedra of Lotus Garden meditation center, the Western center of Her Eminence Jetsun Khandro Rinpoche. I have also taught shorter such courses at various Zen and Vipassanā centers and I also write and teach on-line for widely circulated popular Buddhist periodicals. In this enterprise, I am blessed by the unfailing support of my teacher, Jetsun Khandro Rinpoche, who continues to sponsor the course at Lotus Garden and often reminds resistant Western students that considering a scholarly version of Buddhist history is relevant and important. This Lotus Garden project began with an email to Khandro Rinpoche in 2005 in which I outlined the project in general, but did not propose it as a course of study at Lotus Garden. Some weeks later, in India, I asked her what she thought of the project and she replied that she liked it. On the spur of the moment, I then asked her, "Should we try it at Lotus Garden?"a ${ }^{\text {"She thought }}$ for a moment and said "Yes". Some days later, at a restaurant in Delhi, we again agreed that such a course would be taught. I went back to my table and she went to hers. Then, mindful that most Tibetans believe that the story narrated in the Heart Sütra was a historical event that happened during the lifetime of the historical Buddha and knowing that I would be teaching that Mahāyāna Buddhism developed many centuries after the Buddha's death, I approached her again ${ }^{\mathrm{b}}$. "Rinpoche," I said, "I have to be sure that you understand that most Tibetans would think that much of what I will be teaching is heresy". She laughed heartily and replied, "Oh, that's good for us. It will make us think!".

In the second year of the shedra course, I began serious discussion of the historical origins of Mahayana Buddhism, unequivocally teaching that Nāgārjuna did not retrieve the Mahāyāna teachings from the realm of the $n \bar{a} g a s^{c}$ but that they gradually emerged some centuries after the historical Buddha's life and death and that the Heart Sütra is not a historical narrative. Rather, it is a story. I also tried to help students understand that a story does not have to be empirical history to have religious and spiritual value. But one of the other senior teachers objected greatly, saying that since I had physically stood at the spot where it is said that the Heart Sütra was first spoken, how could I doubt the historical accuracy of the narrative, as if standing at the spot where an event allegedly took place proves that the alleged event did take place in empirical space and time. She also told me that she thought I should desist completely from teaching the history course because it was improper even to bring academic methods into a shrineroom. After the course, one of the residents left the center because he now 
thought that Buddhist stories were no "truer" than many Christian stories. (He was also experiencing personal difficulties at the time and has continued his association with Lotus Garden.) Depending on what I am teaching, over the years, objections have diminished significantly, but they resurface whenever I try to explain that narratives which are unlikely to have been historical events that could have been recorded by a camcorder nevertheless have great value, that their relevance is quite independent of whether or not they are empirical events. I have tried several analogies to try to help them appreciate stories as something other than historical documentaries. As I have thought more about the exuberant miracle stories so abundant in later Indian Buddhist literature, I have come to believe that in their own context they functioned much as science fiction does in our context; it entertains and can present profound messages, even while we understand thoroughly that such narratives do not portray things that can happen empirically in our world at this time. Though some students really appreciated the analogy, others were furious, claiming that I was again belittling Buddhist narratives by using the term "fiction" when referring to them.

\section{Why literalism and fundamentalism?}

What is going on here? Western students of Buddhism do not realize how thoroughly they have imbibed the values of the European enlightenment, especially its definition of truth as something that is empirically verifiable, which is actually a very materialist understanding of truth. But because such students have also decided that Buddhism is "true," they then draw the conclusion that anything claimed by Buddhist tradition must have happened in empirical space and time just as the texts describe it, rather than in any realm of imagination and symbol. People who do not take seriously stories of talking serpents and apples become weak-kneed when confronted by a traditional story about texts hidden in the realm of water-dwelling half-human, half-serpent creatures (the nägas). Probably it is because they do not know how to take seriously stories about talking serpents in the garden of Eden that they feel they must literally believe in stories about nägas if that's what their Tibetan teachers tell them. They have no avenues to assess something as relevant and worthy of consideration except for empiricism and its total reliance on facts alone as trustworthy and valuable. While the cogency of empirical methods and scientific materialism have greatly improved our way of life in many respects, the great loser in this process has been any ability to appreciate symbols, metaphors, and analogies. To many people, symbols are much less convincing than empirically verifiable facts, which is why they insist that anything valuable in a religion must be a fact, not a "mere" symbol. That is why so many religious people entirely lose confidence in their faith tradition when they are no longer able to take its stories literally, when they can no longer believe that Jesus literally rose from the dead or that the historical Buddha himself taught the Heart Sütra and then hid Mahāyāna teachings among the nägas for four hundred years. The motto of such people seems to be "Either it's a fact or it's meaningless. Don't talk to me about symbolism!" Literalism and fundamentalism are toxic to a deep and profound religious life, at least among those who also live by the paradigm engendered by the European enlightenment, which is most of the world these days. In our own day, I believe that one of the most urgent tasks facing serious dharma practitioners is to learn how to take traditional stories seriously without taking them literally. That is to say, we must learn how to live both in 
the paradigm of the European enlightenment and in the paradigms of our various traditions without subjugating one to the other.

Perhaps because I am dealing with Western Buddhists, it is not surprising that I encounter among Buddhists exactly the same attitudes about story and history that my university students displayed. Though technically I was supposed to be teaching Asian religions, I think I spent almost as much time trying to help them appreciate their Christian stories in a non-literal way. To do this, I often relied up one of the wisest statements about history and story that I have ever encountered, spoken by the native American elder Black Elk. He narrated one of the Sioux's most important stories, a story about how the sacred pipe first came to the people. This story is filled with events that are difficult to take literally in the paradigm of European enlightenment ways of thinking, such as women turning into buffalos. Then he said, "This they tell and whether it happened so or not, I do not know; but if you think about it you can see that it is true (Neihardt 1961)".

The main point made in this simple statement is that truth is not always about empirical facts or observable events, contrary to literalist suppositions. Truth reveals itself in deep contemplation of stories and statements. Thus, whether or not a story could have been captured by a camcorder as an empirical fact does not really matter. Its truth lies in its symbolic meanings, found in the realms of imagination and contemplation. Black Elk himself is skeptical about the narrative as a factual account, even though much of his spiritual life is based on the symbolism and rituals associated with the sacred pipe, whose origin is narrated in this story. Thus, the same story could be both true and false at the same time-false as a factual account of an empirical event and true as the symbolic charter for one's spirituality. Only the prestige accorded to facts in the paradigm of the European enlightenment that makes people think otherwise. In more traditional Jewish and Christian strategies of scriptural interpretation, the literal meaning of a text was considered to be quite superficial compared to other layers of meaning and was passed over rather quickly.

This is strategy I propose for dealing with history and story in dharma traditions, though I will confine my own remarks to Buddhism, which I know much more thoroughly than other dharma traditions. As I have already indicated, I would claim that this strategy works even for the monotheistic traditions in which literalism and fundamentalism first became overwhelming. But as the rest of the world rapidly embraces the paradigm of scientific materialism, Buddhists and others are rapidly developing similar rigid attitudes conflating story with history, which involves arguing that traditional narratives and other claims are empirically accurate.

\section{The riddle of modern historical studies and traditional studies}

Religions have had a very hard time adjusting to the paradigm shift engendered by the European enlightenment with its emphasis on rationality and empirical, public verification of claims. In Western circles, this difficulty has usually been seen as a conflict between religion and science, perhaps most vividly played in the controversies about evolution versus creationism that regularly plague school policies and politics in the United States. Buddhism, however, has many fewer problems with science, given that it already envisioned a universe of endless space and time filled with multiple worlds inhabited by diverse creatures. The Dalai Lama's keen interest in and approval of 
modern science increases this impression that modern science and Buddhism can easily get along.

There has been far less discussion of compatibility or conflict between traditional Buddhist narratives and modern historical study, perhaps because no one with the Dalai Lama's stature has taken up this issue. Regarding Buddhism and science, the Dalai Lama is famous for his claim that "If scientific analysis were conclusively to demonstrate certain claims in Buddhism to be false, then we must accept the findings of science and abandon those claims" ${ }^{\prime \prime}$. I make the same claim for the relationship between modern historical studies and Buddhism.

I would also suggest that the implications of modern methods of historical study are more serious than modern science, not only for Buddhism, but for all religions. There are at least two ways in which modern historical methods create doubt about some claims commonly made in traditional narratives. The more serious is the way in which modern historical studies demonstrate, or at least claim, that religious texts, practices, and beliefs are the result of human cultural creativity and evolution. They are products of historical development, not of supernatural intervention into history. In other words, religious texts, practices, and beliefs do not drop, fully formed and nicely bound between two covers, from some other realm into the human realm. The more superficial doubt involves skepticism about the miracle stories so common in traditional religious narratives.

Religions usually resist claims that their forms-their verbally expressed conceptual beliefs and their rituals-are due to human creativity. Every religion, including Buddhism, at least sometimes claims that its forms derive from a seemingly more authoritative source than human creativity. Sometimes, especially in Buddhism, that source is only Tradition, with a capital "T". Many contemporary Buddhist teachers are as submissive before the authority of Tradition as are believers in revealed religions before the authority of their scriptures. "It's established. We can't tamper with those forms" seems to be their mantra. That even a non-theistic religion which does not usually claim to be derived form divine revelation nevertheless relies on an inflexible source for its forms indicates how desperately many humans long to deflect responsibility for their religious forms to some non-human source, or at least some source other than themselves.

However, serious historical and comparative studies, especially if one studies several religions, make it difficult to resist the conclusion that all religious forms, without exception, are human attempts to articulate our relationship with our existential situations. For one thing, it is impossible on any rational and universally relevant basis to adjudicate among the many claims competing to be authentic revelations from beyond the human realm. In a situation of relative religious and cultural homogeneity, which prevailed in most of the world until after global exploration began in earnest in the $16^{\text {th }}$ century, one could be much less aware of these competing claims to be authentic revelation. It is now impossible to avoid awareness of religious diversity and the theological adjustments that all religions need to make in the light of that diversity. But one of the great advantages of living in contemporary times is the adjustments such knowledge requires. When thinking about the religions of others, it is very easy to see them as products of human aspirations and foibles; it is egotistical and perverse to exempt one's own religion from that process. I often remember the logic of some of my 
university students. Their assignment was to apply Black Elk's statement about sacred narratives to two traditional stories, one familiar and the other unfamiliar. The student wrote something like: "The Greeks had very illogical stories that they obviously made up, such as that a mare could become pregnant by turning her hindquarters to the wind. Everyone knows that's impossible. Christians, by contrast, have sensible sacred stories which we didn't make up, such as the Jesus was conceived by the Holy Spirit and had no human father".

Is a dharma tradition such as Buddhism harmed by giving up claims that its teachings transcend human time and space? I think not. In fact, I would claim such a view is more in accord with foundational Buddhadharma than its alternative. I would make this claim on two counts. First, basic Buddhist teachings, such as all-pervasive impermanence and interdependent origination, do not accord well with the supposition that there are eternal verities capturable in words and concepts. Things, including doctrines and rituals, should be expected to change and those changes come about because of changing constellations of causes and conditions. As taught by Nāgārjuna in his famous work the Mülamadhyamaka Kärikās, even the appearance of a Buddha occurs only by the workings of interdependent origination, by the working of the same processes that govern everything else in our human world, not as the result of something transcendent to that world.

Second, I would claim that Buddhism has always taught something also demonstrated by modern historical studies of religion-all religious forms, the words, concepts, practices, and rituals-are human constructions that are culturally relative. In this regard, I see very little difference between the results of modern historical studies of religion and steep/profound Buddhist teachings. I have been very careful in my wording throughout this essay. I have not claimed that there is no ultimate, ineffable, transcendent dimension in human experience; I have claimed that all words and concepts, and so forth, used to point to it are human constructions and should be held lightly, not taken too seriously. The great failing of any religion is always to take its own forms too seriously, to claim that they have ultimate rather than relative significance. Though many Buddhists and non-Buddhists alike often miss the point, in my view, all schools of Buddhism claim that, while teachings and views are necessary and useful tools to be used on the path, ultimately they will be left behind when true insight dawns upon one. Or, as many Buddhists like to say, silence is the ultimate truth-not an uninformed, unpracticed silence, but the silence born of deep contemplation. The silence of not being so attached to words, views, rituals, practices, or any religious forms is ultimately and intensely liberating.

The second way in which modern historical studies cast doubt on traditional narratives is much less serious in my view. Buddhist texts are filled with claims and narratives that are as difficult to believe in literally as either stories of mares becoming pregnant by turning their hindquarters to the wind or of a human child being conceived without a human father. But given that even the most profound teachings, in their verbal and conceptual forms, are tools rather than ultimate truths, it is clearly not necessary to try to take such stories seriously as factual accounts of events, that is to say, to take them literally. Rather, they should be understood as products of their own cultural situation and as relevant in those situations. There are times and places in which stories of miracles and magic make sense to people and have a great deal appeal. 
But we do not live in such a time and place, so trying to force us to take these stories as factual accounts simply makes it harder for us to take the profound teachings of Buddhism, or any other religious tradition, seriously. These are not documents that function well in our contemporary cultural context, post-European enlightenment. In this, I am not claiming that the paradigm of the European enlightenment is an ultimate truth that will stand for all time; it probably will not. Nevertheless, we cannot help standing in that paradigm, which means that our great need to make peace between the prevailing worldview of our culture and the deep and profound teachings of our dharma traditions, not to try to hold onto every single tale of magic and miracles. I myself do not think that the profoundly enlightened masters who wrote texts that include such stories would have written them as they did if they had lived in our cultural situation. That is also to say that whoever is writing the equivalent texts today is probably not going to use miracle stories to prove his or her point.

Actually, regarding stories of magic and miracles, I can find such stories as delightful as anyone else under certain circumstances. Only when they are put to certain uses do I find them misleading and even dangerous. Two ways of using miracle stories are especially problematic. The first is to conflate and confuse story and history. Keeping this distinction clear is extremely useful. Modern history is a scientific, empirically based discipline. Stories are simply stories, not science or history. That science and history have such prestige in our current culture is not a good reason to try to force traditional narratives into that mold. That happens whenever such stories are taken literally, or whenever people seek empirical proofs for traditional narratives, such as, in my favorite example-sending out search parties to find remnants of Noah's ark, as if finding them would prove anything.

The second way in which miracle stories are often used by religions, including Buddhism, is much more problematic. Often a miracle story is used to try to prove that the teachings of a certain leader are indeed true and correct or even that a specific religion is the "true" religion. Countless young university students thought they had defeated me in debate when they proclaimed, "But you can tell that Christianity is the true religion because Jesus performed miracles." They were easily defeated by apprising them of the fact that miracle stories are a dime a dozen, widespread in all religions and, therefore, prove nothing. Given the universality of miracle stories in religions, how could one claim that the miracle stories of one's own tradition prove its truth unless one is willing to grant that all miracle stories found in all religions also prove their truth?

I find it especially problematic when alleged performance of a miracle is taken as the supreme proof of the cogency of a philosophical position. Recently, I attended a program on the teachings of Candrakirti, one of the foremost commentators on Nāgārjuna's teachings on emptiness. Time after time, the teacher would summarize all the philosophical, rational demonstrations for the cogency of Nāgārjuna's teachings on emptiness and then try to clinch his arguments by citing a story of how Candrakirti once extracted milk from a painting of a cow. But if teachings on emptiness were not cogent, I certainly could not be persuaded to believe in them by a story about being able to milk a painted cow, especially given how many non-painted cows I have milked! And if I were to be required to believe in the story of milking a painted cow as fact, that would make me less likely, not more likely, to give credence to teachings on emptiness. (Fortunately, teachings on emptiness are so cogent that the story of the painted 
cow is irrelevant either way.) Why would anyone think this story would be a convincing proof of anything? Clearly, miracle stories are about something other than proving the truth of one specific religion or religious claim among others. It only cheapens both the philosophy and the story to try to use miracle stories to prove a philosophical or religious position. It makes much more sense to let miracle stories function in their own frame of reference as stories in which certain meanings are encoded. Then, our assignment is to contemplate what these stories could mean, rather than to use them as proofs for a philosophical position or to cling to them as descriptions of empirically occurring events.

Many of my dharma friends are troubled by such claims. Their counter to me is often to claim that many of the things we take for granted now-such as wireless transmission of speech and documents across great distance or air travel-are "magical" and would surely have been seen as miraculous by those who lived in earlier times because they seem so impossible. So why not the standard Buddhist miracles, such as flying through space on one's own power, walking through walls, milking painted cows or one of the most famous Tibetan miracle stories-the story of how Milarepa was able to take shelter in a yak's horn during a storm without himself becoming smaller or the yak's horn becoming bigger, while his disciple Rechungpa, who had not yet developed such siddhi or supernatural power, got drenched in the rain?

I would reply to their question in several ways. First of all, the technological marvels dependent on the paradigm shift that occurred during the European enlightenment work, not by contravening physics and natural law but by working carefully within their perimeters. At present, things like walking through walls or milking a painted cow could only be a contradiction of what we understand of natural law to date. Therefore, I neither affirm nor deny such stories but retain a flexible, curious mind about them. Maybe? Show me? Perhaps some day? What would it take to convince me that such events occur in ordinary, empirical space and time? Repeated, public demonstrations of such events, such as happens whenever I use email or board an airplane.

My friends would probably reply that it takes advanced spiritual development to be able to perform siddhi, to have "magical" powers. That some people can do extraordinary, unbelievable things is a claim made by many religious traditions, and I think it is wiser to maintain an open mind regarding such claims than to adamantly deny that they could happen. In addition, given how many seemingly "magical" feats have become common within our lifetimes, who knows in what other ways we will learn to use physics and natural law to perform "miracles" in the future? But I also claim that it is foolhardy to adamantly affirm the veracity of such claims on the basis of hearsay reports of their occurrence-and until such feats are publically verifiable, they remain hearsay. That they are hearsay makes them supremely inadequate for demonstrating the truth claims of Buddhism. I would never attempt to convince others to become Buddhists because I have seen it rain out of clear blue sky at the most auspicious moment of a major Buddhist ceremony. Instead, I would rely on the Four Truths and teachings on emptiness for that task!

\section{Decoding two stories}

When dealing with a seeming conflict between claims stemming from a postenlightenment (European) world view and a traditional story, especially when the post- 
enlightenment version of the story seems more cogent, I always seek to find a deeper consonance between the two claims, rather than rejecting one in favor of the other. Thus, rather than confronting people with the untenablility of the traditional claim, I try to demonstrate that it is possible to find deep meaning in the traditional claim even though it is not accurate as a physical or historical account of things. This practice usually involves using the traditionally claim symbolically while simultaneously holding a modern account of that same phenomenon. When Western Buddhist students simply refused to hear that the historical Buddha had not taught the Heart Sütra during his lifetime on earth, I had to come up with everyday examples of how people routinely continue to use traditional language and symbols long after they are regarded as accurate physical descriptions of how things work. I wanted to convince them they could do the same thing regarding the traditional narrative surrounding the Heart Sütra. I began to detect a glimmer of understanding, some developing flexibility, and less stubborn, fixed mind when I pointed out that we are very comfortable saying "the sun rose" even though we don't believe a word of that statement. The sun doesn't rise; the earth turns. We all know that, and know what we mean when we say, "the sun rose". Why is so hard to do the same with traditional narratives and claims?

\section{Where is mount Meru?}

One of the easiest ways to demonstrate compatibility between traditional Buddhist views and modern knowledge involves the traditional, inherited Buddhist map of the earth. In this picture, the earth is flat, with Mount Meru at the center. Mt. Meru is surrounded by the four continents, each of which is flanked by two islands. These lands are surrounded by the great oceans and the whole thing is encircled by a ring of iron mountains. Clearly, the map of the world we use today does not look anything like this and the fact that geographical exploration of the physical world did not reveal such a map did cause consternation to Buddhists. But if we understand the traditional map of the world to have much more to do with psychology than with geography, the conflict disappears. Until it was proved empirically that one did not fall over the edge of the world if one continued travelling the same direction, but eventually came back to one's starting point, most people simply assumed that the is earth flat. After all, it looks flat, just as it looks from our vantage point as if the sun rises above the earth's horizon. Given that high mountains are found to India's north, it is also easy to see why India was imagined to be the southern continent among the four, with a giant mountain to its north. All were sensible conclusions until proven false empirically. After they have been proven false empirically, it is senseless and useless to try to hold onto such assumptions because of tradition and authority.

In Vajrayāna Buddhist practice, a ritual that utilizes the traditional map of the cosmos is done almost daily. Called "mandala offering," the effectiveness of this ritual has not been diminished in the least by the fact that Western Buddhists who perform the liturgy no longer believe in the literal words of the liturgy. This is because, as I have already claimed, the traditional world-picture and the liturgy based on it have much more to do with psychology than with geography. The short form of the liturgy reads: 
The earth is anointed with perfumed water and strewn with flowers.

It is adorned with Mount Meru, the four continents, the sun and the moon.

By offering this visualized as a Buddhafield,

May all beings enjoy that pure realm.

Clearly, this ritual has little to do with geography. The point of the liturgy is appreciation of the earth, then visualizing it as a Buddhafield, and finally offering everything, both the earth and the visualized Buddhafield, to bring benefit to all beings, enabling them to experience the same felicity that one enjoys oneself. Rather than trying to function as an atlas, this liturgy emphasizes primary Buddhist virtues such as generosity and the wish that all beings could prosper and be happy. That is why it is so easy to continue to do this liturgy daily even while we no longer believe in the description of the earth contained in it. Why is it so difficult to transfer this kind of flexibility to painted cows or to the claim that the historical Buddha himself taught Mahãyanna teachings, including the Heart Sütra?

However, before moving on to further consideration of the story told in the Heart Sütra, it is instructive to consider some other reactions to the conflict between traditional geography of Mt. Meru and the four continents and the modern sense of the earth as a globe suspended in space. In the $18^{\text {th }}$ and $19^{\text {th }}$ centuries, Christian missionaries to Asian Buddhist countries routinely peppered their anti-Buddhist polemics with references to the fact that no explorer had ever found Mt. Meru anywhere on the globe, that traditional Buddhist geographies simply were inadequate as accurate maps of the earth. On this basis, Buddhists were encouraged to exchange their Buddhism for Christianity. Christian missionaries reasoned with Buddhists that if they were wrong about the physical description of the earth, how could they have any insight about spiritual well-being (Lopez 2008)? One can only wonder how many Buddhists were taken in by such arguments. In any case, we cannot help but notice how dangerous it can be to cling to traditional accounts as empirically accurate long after they have been disproved by empirical studies.

Until well into the $20^{\text {th }}$ century, Tibetan Buddhists continued to accept as fact the traditional flat earth traditional geography. In a story that is both amusing and highly instructive, Ken McLoed, one of Kalu Rinpoche's translators, narrates accompanying a traditionally trained Tibetan teacher to northern Canada during the summer. They arrived in the afternoon and settled in for the night, as usual. The next morning the lama was very troubled by the fact that it had not become dark during the previous night. McLeod used apples and oranges to show him how the sun does not set in the summer in northern regions because of the earth's roundness, the way it tilts on its axis, and the way it rotates around the sun. The lama replied that the he had heard the claim that the earth is round when he came out of Tibet, but had dismissed it as another crazy Western idea that was contrary to both everyday sense perceptions and his traditional training. McLeod recounts that the lama was dispirited for some days, but then accepted this new information and returned to his usual cheerful demeanor. His experience of nights without darkness was more powerful than inherited beliefs about the flatness of the earth, even though changing his worldview caused the lama some depression (McLeod 2002). A period of disorientation or depression is a small price to pay for more accurate knowledge. 
Contrast this with the Dalai Lama's excitement and joy at first seeing a photograph of the earth taken from space. Writing about ethics and science, the Dalai Lama is making the point that earth may be the only planet that can support life, so we need to take care of it.

One of the most powerful visions I have experienced was the first photograph of the earth from outer space. The image of a blue planet floating in deep space, glowing like the full moon on a clear night, brought home powerfully to me the recognition that we are indeed all members of a single family sharing one little house ${ }^{e}$.

Here there are no worries about the fact that a traditional Buddhist claim has been disproved, that the earth is not flat and that Mt. Meru is no where to be found in the photograph. Instead, easily adjusting to a more complete, and in this case, more empirical geography, the Dalai Lama is free to draw relevant ethical conclusions from this newly found knowledge.

But others seem to have more difficulty coping with the information conveyed in photographs of the earth taken from space. At the end of his chapter on traditional Buddhist geography in his book Buddhism and Science, Donald Lopez narrates that in 1977, he was discussing traditional geography with a prominent lama. He asked the lama why Mt. Meru had never been discovered. Lopez noted that they were speaking in Tibetan and the answer could have been translated in two ways: "The first would be, 'If you have pure karma, you can see it'. The second would be, 'if you had pure karma, you could see it" ${ }^{\prime \prime}$. At first, this answer seemed merely like stubborn literalism to me. But perhaps the lama meant that one could understand that, empirically, the earth is round not flat but at the same time one could continue to perform the mandala offering liturgy as it had been done for centuries without any contradiction whatsoever. The mind can simultaneously hold both empirical reality and symbolic meaning, even though, superficially they are quite different. It is not necessary to cling to the literal world picture of the mandala offering liturgy to continue to offer a visualized world for the benefit of all beings.

\section{The story of the Heart Sutra}

Several times in this paper, I have alluded to resistance to historical accounts of the origins of Mahāyāna Buddhism and to persistent clinging to traditional accounts of how the Buddha taught Mahāyāna teachings but then had them hidden for about four hundred years. Indeed, over the years this has continued to be the most controversial topic about which I teach, at least in Mahāyāna contexts. (I have taught much less in Theravāda contexts, but presumably, they would be equally resistant to being asked to study Mahāyāna texts and teachings seriously).

What is at stake for Mahāyāna Buddhists that makes them so fearful of letting go of literal interpretations of the Heart Sütra? Why is it so difficult for them to relax their adamant claims that this story has to be more that a story-that it has to be history as well? Clearly, these fears and anxieties stem from the fact that Mahāyānists want to believe that the historical Buddha secretly taught Mahayana teachings to selected students and that those students usually did not include the foremost historical 
students of the historical Buddha. The fear seems to be that Mahāyāna Buddhism would somehow be inauthentic if they were not the direct teachings of the historical Buddha himself.

But Mahāyāna Buddhism displays so many features of a new religious movement that any scholar of religious history would immediately identify it as such. The first is that older Buddhist schools have scant references to Mahāyāna Buddhisms in their texts and rarely bother to refute their teachings, indicating that the older schools of Buddhism did not perceive them as much of a threat. By contrast, Mahāyāna texts constantly justify themselves by contrasting themselves very positively with the older, more established schools, whom they label as "Hinnayāna"-the inferior, cast-off yāna. Both tendencies are very common when a new religious movement is emerging. The older schools don't spend much time worrying about the new movement, but the new movement constantly criticizes the older movement as inadequate, thereby justifying its own deviation from the older schools. For example, Jews don't spend a lot of time or energy denouncing Christians, but the Christian New Testament is full of claims about the inadequacy of Judaism. The same thing happened with the emergence of Islam. The story is much the same with Mahayana Buddhism and the older Buddhist schools.

Even the Mahāyāna myth about its own origins betrays that it is a new religious movement. When it is claimed that the historical Buddha taught Mahāyāna teachings, it is also often taught that the Buddha's older students were very shocked at what the Heart Sutra has to say, whereupon the Buddha realized that his students needed to mature for some hundreds of years before they would be ready to understand these teachings. Thereupon, the Buddha hid the teachings among the naggas, from where they were retrieved some four hundred years later by Nāgārjuna. Ironically Buddhist legendary history corresponds exactly with empirical studies of Buddhist history on this point. Both agree that Mahāyāna teachings appeared on the human plane about four hundred years after the life of Saakyamuni Buddha, which indicates to me that early Mahāyānists were fully cognizant that they were teaching something previously unheard. In fact, all their sutras say precisely that; they all claim that the Buddha is now teaching something he had not revealed previously. That they felt a need to somehow attribute these teachings to the Buddha is not surprising. When people innovate within an established tradition, they always claim direct inspiration from the example and teachings of the founder. What is surprising and untenable from the point of view of empirical history is that in later centuries, people took these stories as actual conversations between the historical Buddha and his historical disciples, rather than as deeply contemplative, imagined conversations between a prototypical Buddha and his prototypical disciples on topics of interest to contemporary practitioners.

What is even more surprising is that contemporary Western students of Buddhism take the Heart Sütra as a historical narrative despite the mix of historical and nonhistorical characters in its plot. As already mentioned, the sūtra is basically a conversation between Shariputra, a representative of the older Buddhist schools, and Avalokitesvara, a non-historical bodhisattva important in Mahāyāna Buddhisms, who did not even emerge as an important figure in Mahāyāna Buddhism until centuries after the death of Shariputra. As is usual in Mahāyāna sütras, Shariputra doesn't know what's going on and has to be instructed by the Mahāyāna bodhisattva. This cast of characters alone should disabuse anyone of the notion that the Heart Sütra could be 
history. Shariputra is a historical character, whereas Avalokitesvara is not, so the narrative could not be history, even though it is an incredibly important story for Mahāyāna Buddhists. The fact that I have physically stood on the spot where the sütra was supposedly spoken does nothing to make it history. The historical Buddha taught many sütras at Vulture Peak Mountain, the historical site in question. But he did not preside over the recitation of the Heart Sütra at that spot. Even the Dalai Lama basically concedes that point. He writes:

When we examine the Mahāyāna scriptures themselves, we find statements that seem problematic in various ways. For example, the Perfection of Wisdom sütras state that they were taught by the Buddha at Vulture Peak in Rajagriha to a vast congregation of disciples. However, if you have visited the site in present day Rajgir, it is obvious that it is impossible for more than a few people to fit onto the summit. So we have to understand the truth of these accounts at a different level, a level beyond the ordinary one confined by conventional notions of space and time (Gyatso 2005).

That is precisely what I have been advocating with the help of Black Elk's succinct and profound statement. Give up on even trying to read the Heart Sutra as empirical history. Then, as separate but intertwined projects, take up, first, ascertaining an empirical account of the emergence of Mahāyāna Buddhism and second, interpreting the symbolism and meaning of the Heart Sütra on a level beyond ordinary space and time. But don't confuse and conflate the two.

Furthermore, Buddhism actually has cogent and appropriate tools for working on an empirically accurate understanding of the emergence of Mahāyāna Buddhism. We are not limited to conceding defeat in the realm of empirical history and borrowing the tools of the European enlightenment. As I have written in another context (Buddhist History for Buddhist Practitioners Fall 2010), core Buddhist teachings-all pervasive impermanence and interdependent origination-explain very well, without recourse to causes that cannot be empirically verified, how and why Buddhist teachings have grown and developed over the centuries. No teaching is more basic to Buddhism than the teaching that everything changes. Therefore, one should expect that over the centuries, changes will occur in Buddhist institutions, practices, and even in how the verbal, conceptual dharma is put into words. One should expect that new movements would develop. There is nothing shocking or out of the ordinary about that. Furthermore, teachings on interdependent origination explain very cogently how those changes occur, dependent on a complex matrix of causes and conditions, without recourse to supernatural intervention into these processes.

When we actually examine the matrix of interdependence out of which Mahāyāna emerged, the situation is rather messy and very complicated. Religious people tend to prefer an uplifted, neat narrative about the origins of their particular lineage which may well explain why "insider's" "histories" of the development of Mahāyāna Buddhism have been more legendary than empirical. But what about honesty and full disclosure? Fortunately, we also have very cogent "insider" tools for working on a more complete and more empirically accurate history of Buddhism-all pervasive impermanence and interdependence. 


\section{Conclusion}

In conclusion, I want to make only two points. The first is that while I have stressed empiricism a great deal in this paper; that is only because I am dealing with history and trying to unravel history from story, which is essential to discerning an accurate and non-sectarian history of Buddhism. As for the Buddhist religion itself, many aspects of its teachings and claims are trans-rational (not irrational) and beyond anything that can be reached with empirical methods. We can study the history of how those claims developed, but we cannot prove or disprove them with empirical methods. The heart of Buddhism deals with a state of mind first pointed out by the Buddha when people would ask him about the state of enlightened being after the death of the physical body. He always refused to answer that question in any concrete way, saying instead that nothing could be said about such an experience, that he neither existed, nor did not exist, nor both existed and did not exist, nor neither existed and did not exist. Baffling and popping discursive mind with such enigmatic but pregnant statements has always been at the heart of Buddhist teachings and disciplines. I can trace of history of such statements from those attributed to the historical Buddha in the Pali texts to the writings of Nāgārjuna and into Mahāmudrā, Dzogchen and Zen teachings. There is a history to their transmission from generation to generation and there is no need to bring non-empirical elements into that history. But more than that, we cannot do with history.

Finally, just as I have sometimes lamented that I have had to do so much work on gender, I sometimes lament that I am now given the task of teaching people the difference between history and story, which means demonstrating that some of their beloved stories simply are not history. That they are not history does nothing to rob them of their meaning and value, but it is very hard to get empirically oriented, postEnlightenment (European) Western Buddhists to get that point. I regret this because no one loves a good story more than me and I love to tell sacred stories from the great traditions. But if I have to watch people to see if they are taking the story literally, that spoils some of the fun. If one takes stories literally, confusing them with empirical events, all the whimsy, humor, and playfulness of the story is lost and it becomes completely wooden-spoiled in every way because it is not good history and it is no longer a good story either. So please, let us not confuse and conflate story and history!

\section{Endnotes}

a (http://www.lotusgardens.org/).

${ }^{\mathrm{b}}$ The Heart Sutra is almost the charter document of Mahayana Buddhism. It is represented as a dialogue between Shariputra, a historical character and major disciple of the Buddha, and Avalokiteshvara, a non-historical bodhisattva, that takes place while the Buddha watches and approves of Avalokiteshvara's teachings. Its most famous line is "form is emptiness and emptiness is form".

${ }^{c}$ Many Tibetans explain the long gap between the lifetime of Shakyamuni Buddha and the emergence of Mahayana teachings by claiming that after the Buddha taught these teachings, he realized that his disciples were not yet ready to hear them, so he hid them in the realm of the nagas (half-human, half-serpent creatures who dwell in watery places) from where they would be retrieved at a later date when ordinary humans were more prepared to understand Mahayana teachings. 
${ }^{d}$ His Holiness, the Dalai Lama, The Universe in a Single Atom: The Convergence of Science and Spirituality (New York: Morgan Road Books, 2005), p. 3.

${ }^{\mathrm{e}}$ His Holiness, the Dalai Lama, p. 261.

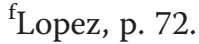

\section{Competing interests}

The author declares that she has no competing interests.

\section{Author's information}

Rita M. Gross, Ph.D. is former Professor of Religious Studies at University of Wisconsin, Eau Claire. She is also a Buddhist dharma teacher (Lopon) having been appointed to that position by Her Eminence Jetsun Khandro Rinpoche. Email: grossrm@uwec.edu.

Received: 14 October 2013 Accepted: 15 October 2013

Published: 27 January 2014

\section{References}

Buddhist History for Buddhist Practitioners. Fall 2010. Tricycle: The Buddhist Review, Vol. XX, No. 1, 83-5. 118-20.

Gyatso, T. 2005. The Fourteenth Dalai Lama, Essence of the Heart Sutra, 46-7. Boston: Wisdom Publications.

Lopez Jr, DS. 2008. Buddhism and Science: A Guide for the Perplexed, 41-57. Chicago: University of Chicago Press.

McLeod, K. 2002. Wake up to your life: discovering the Buddhist path of attention, 353-4. San Francisco: Harper and Row.

Neihardt, JG. 1961. Black Elk Speaks: Being the Life Story of a Holy Man of the Oglala Sioux as told through John G.

Neihardt, 5. Lincoln, Nebraska: University of Nebraska Press.

doi:10.1186/2196-8802-1-5

Cite this article as: Gross: Historical consciousness and traditional Buddhist narratives. International Journal of

Dharma Studies 2014 1:5.

\section{Submit your manuscript to a SpringerOpen ${ }^{\circ}$ journal and benefit from:}

- Convenient online submission

- Rigorous peer review

- Immediate publication on acceptance

Open access: articles freely available online

- High visibility within the field

Retaining the copyright to your article

Submit your next manuscript at $\boldsymbol{\nabla}$ springeropen.com 